\title{
SUMMARY OF TITANIUM STUDIES \\ IN SUPPORT OF FUSION ENERGY
}

\author{
Compiled by
}

\author{
J. W. Davis
}

\section{May 1980}

\section{Mำ}

PoRTIOHS of TMIS REPOST APE MLLERS

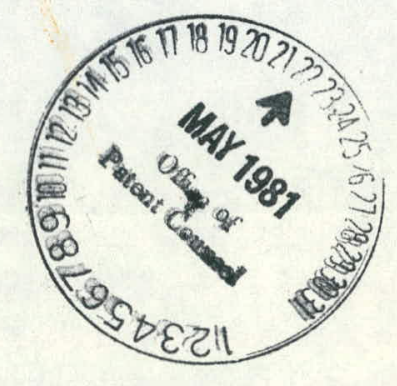
it has been reprowermit the broadest avalable copy

\author{
Prepared for \\ the U. S. Dept. of Energy \\ Under Contract No. EG-77-02-4247
}

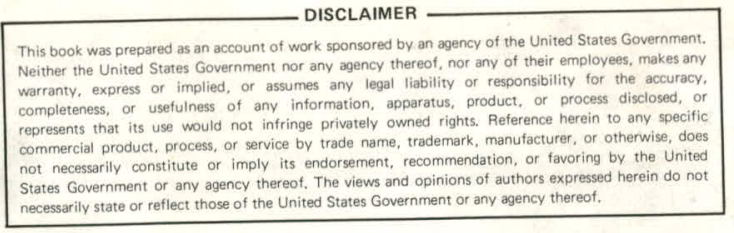

MCDONNELL DOUGLAS ASTRONAUTICS COMPANY-ST. LOUIS DIVISION

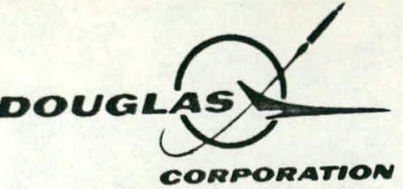




\section{DISCLAIMER}

This report was prepared as an account of work sponsored by an agency of the United States Government. Neither the United States Government nor any agency Thereof, nor any of their employees, makes any warranty, express or implied, or assumes any legal liability or responsibility for the accuracy, completeness, or usefulness of any information, apparatus, product, or process disclosed, or represents that its use would not infringe privately owned rights. Reference herein to any specific commercial product, process, or service by trade name, trademark, manufacturer, or otherwise does not necessarily constitute or imply its endorsement, recommendation, or favoring by the United States Government or any agency thereof. The views and opinions of authors expressed herein do not necessarily state or reflect those of the United States Government or any agency thereof. 


\section{DISCLAIMER}

Portions of this document may be illegible in electronic image products. Images are produced from the best available original document. 


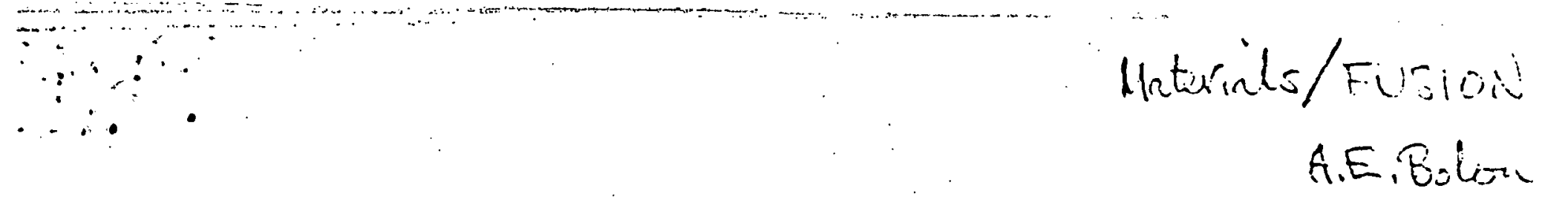

\section{RADIATION DN'ACE IN TITANILA ALLOYS*}

$$
\begin{gathered}
(T i-6 A 1-4 V) \\
(T i-15 V-3 j n-3 C r-3 F \\
\text { tread rizad } \\
7 / 11 / 80
\end{gathered}
$$

S. M. L. Sastry and J. E. O'xieal McDonnell Douglas Research Laboratories St. Louls, M10 63166

J. W. Davis /

McDonnell Douglas Astronautics Company St. Lou1s, $M 063166$

\section{Introduction}

Titanium alloys are anong materials being considered for the first wall and blanket structure of a fusion reactor. Titanilo alloys are of interest because of their low long-term residual radioactivity and the attractive comblration of thermophysical and mechanical properties which result in 10 w thermal stresses high fatizue strength, and high fracture toughness. Previous studies $(1,2)$ of neutron irradiation effects in pure titanium indicate that at Irradiation temperatures of $335-800^{\circ} \mathrm{C}$ and neutron fluences $=10^{21}$ neutrons $/ \mathrm{CD}^{2}$, itanium is resistant te void ferration and shelling. The early studies of neutron radiation danage in titaniua alloys [3,4] were performed at Irradiation terperatures and fluences much lower than those of a fusionreactor first-wall structure environment. In a recent investigation, Wilkes and Kulcinskil $\left\{{ }^{2}\right.$ studied the damage microstructure in mill-annealed $\mathrm{T}:-6 \mathrm{~A} 1-4 \mathrm{~V}$ 1rradiated rith i $7 . j-:$ produced nonequilibricu fine precipltates in the alpha phase in addition $=0$ the expected defect clusters, dislocation loops, and dislocation tangles. f1rst indication of void formation in eltanium alloys was reported by vol ibj

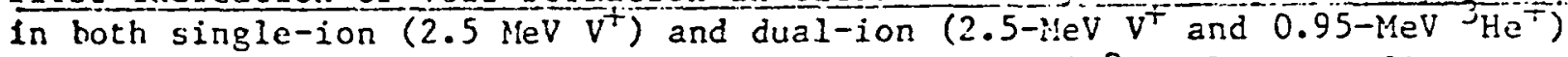
Irradiated $\mathrm{Ti}-6 \mathrm{Al}-4 \mathrm{~V}$ at temperatures greater than $540^{\circ} \mathrm{C}$. Ion irradiation, which alters the local chenical composition of the alloy matrix in addicion to producing displacement damage, may not be indicative of high-energy neutron 1rradiation. Preliminary results of irradiation creng studies of titanium alloys have been reported recently \{\} , and radiation damage studies of titaniun alloys irradlated to higher fluences are in progress. The crystallographic features of the neutron-radiation-induced defect structure, radiation-induced precipitation of nonequilibrium phases, and anealing of damige microstructure determined by transmission electeco microsconic cramination of variously heat-treated alnha-beta, alpha, and beta-citaniun alioys irradiated to a fluence of $3 \times 10^{2.1}$ neutrons/cri $\left(E_{n}>0.1 \mathrm{HeV}\right)$ are reported here.

\section{Experimental Procedure}

The compositions and heat treatments of the different titanium alloys studicd are given in Table 1. Rectangular $50 \times 6.4 \times 1.0$-men cross-section spectrens were prepared from the 1.0-nm sheet stock. supplied by the olloy producers.

*This wark was supported by U. S. Dept. of Energy under Contract No. EG-77-C$02-4247$. 
The specimens were 1 rradlated at $450+30^{\circ} \mathrm{C}$ in Row VII of the EBR-II reactor to a fluence of $3 \times 10^{21}$ neutrons $/ \mathrm{cm}^{2}\left(E_{n}>0.1 \mathrm{MeV}\right)$. The resulting damage in these alloys was 2.1 displacements per atom. Following irradiation, the specimens were chea-milled to $0.3 \mathrm{~mm}$ thickness in a solution of nitric acld, hydrofluorlc actd, and water malntalned at $0^{\circ} \mathrm{C}$, and $3-\mathrm{mm}$ dian discs were prepared from the chem-milled sheets. Specimens for optical metallographic examination were prepared by mechanical polishing of the 3-mm diam discs using 3-Hm diamond abrasive. A twin-jet electrolytic thinning technique using methanol-butanol-perchloric acld electrolytel8] was used for preparing specimens for transmission electron microscopic examination. The temperature of the electrolyte during thinning was maintained below $-15^{\circ} \mathrm{C}$ to prevent hydrogen pick-up and hydride formation. The thin folls were examined in a JEOL JEM 100B electron microscope operated at $100 \mathrm{kV}$. To quantify the irradiation-induced defect microstructure, grains of several different orlentations were examined using bright-iield, conventional ciark field, and weak-beam dark-field techniques. The nature of dislocations and dislocation loops was determined by standard contrast experiments under two-bean conditions, and the small defect clusters were identified using the line-ofcontrast criterion [9] and black-white vector orientation criterion [10,11]. The hardness values of unirradiated and irradiated 3 -tw discs were determined using a Leitz microhardness tester with a 50-g load.

\section{Results}

\section{3:1 Dest-Irradiatian Misrostructures of Tttanium Alloys:}

The microstructures of duplex annealed Ti-6AI-4V in the unirradiated and Irradiated conditions are shown in Figs. la and lb. The unirradiated

(microstucture (Fig. la) consists of large volume fractions of equiaxed 5-10 $\mu$. primary alphe grains and small volume fractions of Widmanstätten alpha-beta plates and intergranular beta./The microstructures of the irradiated specimens consist of a high density of small dislocation loops and dislocation debris along wlth 10-20 nn sirc ellipsoidal precinitates. The precipitates Imaged in dark field with a precipitate reflection are shown in F1g. $2 a$. The precipltates, identified by selected-area electron diffraction (SAD) analyses (Figs. 2b and 2c) were body-centered-cubic beta nhase with a lattice spacing of $0.302 \mathrm{ng}$. The orlentations of the precipitates with respect to the alpha. matrix confora to the Burgers orientation relationships of $\{0001\} \alpha \|\{10\}_{B}$ and $\langle 11 \overline{2} 0\rangle_{\alpha}\langle 111\rangle_{\beta}$. The beta precinitates form nreferentially alone dislocation lines, low-angle boundaries, and grain boundarics. The post-irradiation microstructure of mill-annealed $\mathrm{Ti}-6 \mathrm{Al}-4 \mathrm{~V}$ is similar to that of duplex anncaled $\mathrm{T} 1-6 \mathrm{MI}-4 \mathrm{~V}$. The microstructure of irradiated beta-annealed $\mathrm{T} 1-6 \mathrm{Al}-4 \mathrm{~V}$ shown in Fig. 3 indicates that the basic Widranstätten structure is retained after irradiation, and the principal radiation-induced defect structure in the alpha phase is similar to that in mill-annealed and duplex-annealed $\mathrm{Ti}-6 \mathrm{Al}-4 \mathrm{~V}$.

Figures $4 a$ and $4 b$ are the electron micrographs of the defect structure in the lrradiated near-alpha alloys. The defect scructure cuuststs of a high density of prismatic dislocation loops, small defect clusters, and c-component dislocations. In contrast with the extensive beta precipitation in Ti-6il-iv, there was no Indication of beta precipltation in the near-nlpha alloys. The $S \triangle D$ patterns of the 1rradiated near-alpha alloys showed faint extra reflections colncldent with $\mathrm{TH}_{3} \mathrm{Al}$ reflections, but well-defined contrast from 
the $\mathrm{Tl}_{3} \mathrm{Al}$ preclpitates could not be obtained because of the small size of the precipitates. $\mathrm{I}_{3} \mathrm{Al}$ formation may not be a radiation induced phenomenon because $\mathrm{Tl}$ Al preclpltates have been observed fa glpha-rlch titanlum alloys isothermally aged for long times at $400-500^{\circ} \mathrm{C}$

The defect structure 1maged with a strongly exclted (0002) reflection (F1gs. $5 a$ and 5b) shows a large number of defect clusters with black-white contrast. Although spherically symmetrlcal clusters and small dislocation loops show each black-white contrast under two-beam diffraction conditions, the black-whlte vector (I) is always parallel to $g$ for spherical strain centers. Examination of the defect clusters shown in Fig. 5a under different $\&$ vectors indicate that a significant number of the clusters are small dislocation loops with a c-component Burgers vector. Figure $5 b$ taken with $g=$ $(0002)$ (thus rendering all the a/3 [1120] dislocations out of contrast) shows dislocations with c-component Burgers vector detained at small dislocation 10ops.

The microstructure of unirradiated solution-treat-and-aged $\mathrm{Ti}-15 \mathrm{~V}-3 \mathrm{Sn}$ $3 \mathrm{Cr}-3 \mathrm{Al}$ alloy shown in F1g. 6 a consists of homogeneously distributed $40-100 \mathrm{ng}$ size alpha precipitates in the beta matrix. Aftcr irradiation, the alpha preclpitate density increases slightly, and the coarse elongated alpha precipitates acquire a globular morphology as seen at $A$ in Fig. 6b. The substructure in the beta phase consists of a high density of defect clusters and prismatic loops, which are shown at location $B$ in Fig. 6b. The details of the defect structure in the alpha phase were too fine to be resolved.

The offocts of neutran frradfatinn on the miernhardness nf the alnha-heta and near-alpha alloys are shown in Fig. 7. Neutron irradiation results in an increase in hardness in both alpha-beta and near-alpha alloys. The irradiated alpha-beta alloy containing both defect clusters and fine precipitates show's a larger increase in hardness than the near-alpha alloys containing only defect clusters.

\subsection{Post-Irradiation Annealing of Titanium Alloys:}

The temperature dependence of annealing of the neutron-irradiationInduced defect structure was determined by transmission electron microscopic cxamination of annealed bulk specimens and specimens ancealed in the heating stage of the electron nicroscope. In-situ annealing at $500^{\circ} \mathrm{C}$ for 10 ain did not result in significant microstructurai changes excep: for a limited amount of defect annihilation. Increasing the temperature to $560^{\circ} \mathrm{C}(\sim 0.43 \mathrm{~T})$ resulted in a rapid annihllation of dislocations and dislocation loops and their coalescence into larger defrets. Figures $8 a$ and $8 \mathrm{~b}$ show the same region of an 1rradiated duplex-annealed $\mathrm{T} i-6 \mathrm{Al}-4 \mathrm{~V}$ spectmen after in-situ annealing for $10 \mathrm{~min}$ at $500^{\circ} \mathrm{C}$ and $560^{\circ} \mathrm{C}$, respectively. In contrast with the continued presence of beta precipitates in the in-situ annealed sample, bulk annealing at $650^{\circ} \mathrm{C}$ resulted in complete annihilation of radiation induced defects and disssolution of bcta precipitates by the alpha matr1x (F1g. 9a). The difference between the bulk annoaled and in-situ annealed specimens caused by surface effects and possible contamination of the specimen in the electron microscope suggest that care mist be exercised in obtaining conclusions from in-situ annealing experiments. The radiationinduced-defect structure in the near-alpha alloy also ancals out at $650^{\circ} \mathrm{C}$, 
resulting in the formation of dislocation networks as shown in Fig. $9 \mathrm{~b}$.

The effects of post-irradiation annealing on the hardness of the alloys are shown in Fig. 10. The decrease in hardness with increasing aninealing temperature is in agreement with the recovery of radiation-induced microstructure determined by transmission electron microscopy.

\section{Discussion}

The most prominent microstructural modfications resulting from neutron Irradlation of titanium alloys to a damage level of 2.1 defects per atom are the production of a high density of defect clusters, dislocation loops, and dislocations with nonbasal slip vectors in all alloys, and precipitation of fine beta phase in the alpha-beta alloy. The general characteristics of the defect structure are similar to those observed in other alloy systems (13-15) irradiated with high-energy neutrons, and the crystallographic features of defects in the alpha phase of the irradiated near-alpha and alpha-beta alloys are in agreement with the operative slip systens in binary Ti-Al alloys (1618). Although both a-type slip, $(a / 3\{10 \overline{1} 0\}\langle 1 \overline{1} 0\rangle)$, and c-component slfp have been observed in binary $\mathrm{T} i-\mathrm{Al}$ alloys, the predominant deformation mode $1 \mathrm{~s}$ the a-type slip in alloys deformed at $25-700^{\circ} \mathrm{C}$. Because the $\{10 \overline{1} 0\}$ planes are the close-packed planes in $\mathrm{T} i-\mathrm{Al}$ alloys, the point defect clustering into dislocation loops of $a / 3\langle 1 \mid \overline{2} 0\rangle$ Burgers vector should readily occur in $\{10 \overline{1} 0\}$ planes. The dislocation loops seen in the 1rradiated $T i$ alloys are in agreement with the expected $a / 3\{10 \overline{1} 0\}\langle 11 \overline{2} 0\rangle$ loops, and similar results have been reported in zirconiu $(19-20)$. However, in contrast with the exciusive a-type dislocation loops reported in irradiated 2 irconium, neutron irradiation of titanium alloys results in a significant number of e-cosponent dislocations and dislocation loops (Fig. 8).

The defect clusters produced by neutron irradiation act as thermally activated barriers to dislocation motion and increase the yield stress of the alloy. Examples of dislocations held at point defect clusters are seen in Figs. 2, 6, 7 and 8. The stress (Y) necessary to overcoice the point defect cluster barriers is given by (21) $L K$

$$
\tau=\alpha \mu b \sqrt{N d}, T
$$

where $a$ is a constant, $\mu$ is the shear nodulus of the matrix, $b$ is the Burgers vector of the dislocation, $\mathrm{N}$ is the number of defect cluster barriers, and $\mathrm{d}$ is their average size. The increase in hardness in the irradiated alloys (shown In Fig. 15) is in qualitative agreement with the strengthening expected from the defect clusters.

The dominant feature of the radiation-induced damage microstructure in the alpha-beta alloy is the dense precipitation of fine beta precipitates. The absence of such precipitation in isothermally annealed, unirradiated, Ti6Al-4V alloys and the dissolution of the preclpltates upon high-temperature annealing of the 1rradiated alloy indicate that beta preclpitation occurs by radiation-induced solute segregation to point defect clusters rather than by radiation enhanced fiffusion in the supersaturated alpha matrix, as was sugfested by Nygren $\{7$. Because vanadium in titanium has negative misfits of $-3 \%$ on the a-axis and $-6 \%$ on the c-axis, the segrcgation of vanadium to radiation-induced point defects is facilitated, and the solute enrichment of defect clusters is further enhanced by increased diffusion rates in the 
1rradlated alloy. When the locallzed vanadlum segregation exceeds the solubllity 11mit, beta preclpltates nucleate. Local enrichment of undersized atoms and depletion of oversized atons at defect sinks and the consequent formation of nonequillibriun preclpitates and preclpitate-free zones have been observed in $\mathrm{N} 1-\mathrm{SI}$ and $\mathrm{N1}-\mathrm{Al}(23-24)$. The preferential preclpitation of beta phase at vacancy sinks such as dislocation lines, low-angle boundaries, and high-angle boundarles (F1g. 3) Indicates that the preclpitation is caused by radiation-induced solute enrichment, with other radiation induced/enhanced phenomena such as changes in the free energles of alpha and beta phases and enhancement of diffusion rates by a large supersaturation of vacancies aiding the precipitation.

The compostions determined by $x$-ray energy dispersive analyses of alpha and beta phases of $\mathrm{T} 1-6 \mathrm{AI}-4 \mathrm{~V}$ annealed at $700-900^{\circ} \mathrm{C}$ and slowiby cooled to room temperature revealed no appreciable supersaturation of vanadium in alpha. Furthermore, the equilibrium volume-fraction of beta phase in $\mathrm{T} 1-6 \mathrm{Al}-4 \mathrm{~V}$ is significantly lower at the irradiation temperature of $450 \pm 30^{\circ} \mathrm{C}$ than at the temperatures at which the alloy was annealed prior to irradiation. These results, coupled with the observation that dissolution of beta precipitates in irradiated $\mathrm{Ti}-6 \mathrm{AI}-4 \mathrm{~V}$ occurs at $650^{\circ} \mathrm{C}$, discount the possibility of equilibrium precipitate formation by enhanced diffusion in the supersaturated alpha matix of $\mathrm{Ti}-6 \mathrm{Al}-4 \mathrm{~V}$.

The radiation-induced beta precipitates in $\mathrm{Ti}-6 \mathrm{Al}-4 \mathrm{~V}$ impart additional strengthening to the alloy as evidenced by a larger increase in hardness in T1-6Al-4V than in the near-alpha alloys irradiated to identical fluences. The precipltates could also signiflcantly reduce swelling by capturing the defects and reducing the flux of vacancies to volds, an attractive feature, from an alloy design viewpoint.

\section{Summary and Conclusions}

High-energy neutron irradiation of $\mathrm{Ti}-6 \mathrm{Al}-4 \mathrm{~V}$ results in extensive defect clusters, prismatic loops along with fine ellipsoidal, 10-20 nm beta precipitates with orientation relationships $\{0001\}_{\alpha} l i\{110\}_{B}$ and $\langle 1120\rangle_{\alpha} \mid\langle 111\rangle_{\beta}$. The beta precipitates redissolve upon annealing the irradiated alloy at $650^{\circ} \mathrm{C}$. The causes of beta precipitation were identified to be radiation-enhanced diffusion and radiation-induced segregation of the undersized heta stabilizing element, vanadium, to the defect clusters. The radiation-induced defect structure in the near-alpha alloys consists of a high density of defect clusters, a/3<1/20> prismatic dislocation loops, and c-component dislocations and vacancy loops with no indication of beta precipitation. The increase in hardness as a result of irradiation is greater in $\mathrm{Ti}-6 \mathrm{Al}-4 \mathrm{~V}$ than in the nearalpha alloys because of the precipitation strengthening by radiation-induced, Iine, beta precipltates. The radiation damage of the alloys anneals out coupletely at $650-750^{\circ} \mathrm{C}$.

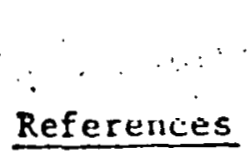

1. Y. Adda, in Proceedings of Int. Conf. on Radiation Induced Volds in Metals, Conf. 710601, Albany, NY, 1971, ed. by J. W. Corbet and L. C. Inniello, United States Atonic Encrgy Commission, 1972, p. 31-83. 
2. J. C. Brimhall, H. E. Kissinger, G. L. Kulcinsk1, in Proceedings of Int. . Conf. on Radiation Induced Volds in Metals, CONF 710601, Albany, NY, 1971, ed. by J. W. Corbet and L. C. Ianniello United States Atomic Energy Commission, 1972, p 338-362.

3. R. A. Hasse and C. B. Hartley, NASA Technical Memorandum, NASA TM X-2678, 1972.

4. C. E. de Bogdan, NASA Technical Memorandum, NASA TM X-2883, 1973.

5. P. W1lkes and G. L. Kulcinsk1, J. Nucl. Matl., 78 (1978), p. 427.

6. F. V. Nolf1, in Damage and Fundanental Analysis Studies Quarterly Progress Report, (DOE/E7-0065/3, May 1979), p. 137 .

7. R. E. Nygren, J. Nucl. Mat 1., 86, 87, part B, (1979), p. 86.

8. M. J. Elackburn and J. C. Williams, Trans. TMS-AIME, 239 (1967), p. 287.

9 G. Thomas and W. L. Bell, in Lattice Defects and Their Interaction, ed. by R. R. Hasigut1, (Gordon and Breach, New York, 1967), p. 478.

10. M. Wilkens, in Modern Diffraction and Imagining Techniques in Materials Science, ed. by S. Anelinkx, R. Grevers, G. Remaut and J. Van Landuyt, (North Holland, Ansterdam, 1970), p. 233.

11. M. Ruhle, Phys. Status Solidi, 19 (1967), p. 263 and p. 279.

12. G. Welsch, G. Lutzering, K. Gazioglu, and W. Bunk, Met. Trans, 8A (1977), p. 169.

13. M. Wilkens, in Fundamental Aspects of Radiation Damage in Metals, ed. by

M. T. Robinson and F. W. Young, (CONF - 751006Pl, Gattinburg, PA, 1975),

p. 98-112

14. G. L. Kulcinsk1, in Applications of Ion Beams to Metals, ed. by S. T. Picraux, E. P. EerNisse, and F. L. Vook, (Plenum Press, New York, 1974), p. 613.

15: I. O. Stiegler end I. K. Mensur, Annual Reviey af Matertels Setence, Yal. 9, ed. by R. A. Huggins, R. H. Bube, and D. A. Vermilyea, (1979), p. 405.

16. T. R. Cass, in The Science, Technology and Application of Titaniun, ed. by R. I. Jaffee and N. E. Promisel, (Pergamon Press, New York, 1970), p. 459.

17. N. E. Paton, J. C. Williams, and G. P. Rauscher, in Titanium Sclence and Technology, ed. by R. I. Jaffee and H. M. Burte, (Plenum Press, New York, 1973), p. 1049.

18. S. M. L. Sastry and H. A. Lipsitt, Acta Met., 25 (1977), p. 1279.

19. P. M. Kelly and R. G. Blake, Phil. Mag., 28 (1973), p. 415.

20. A. Jostons, P. M. Kelly and R. G. Blake, J. Nucl. Matl., 66 (1977), p. 236.

21. J. D. Moteff, D. J. Michel, and V. K. Sikka, Nucl. Met., 18 (1973), p. 198.

22. D. I. Potter and H. A. Hoff, Acta Met., 24 (1976), p. 1155.

23. D. I. Potter and D. G. Ryding, J. Nucl. Matl., 71 (1977), p. 14.

24. N. Q. Lam, P. R. Okamoto and R. A. Johnson, J. Nucl. Mat1., 78 (1978), p. 408.

Reponts $*$ Preprints Resnoved. 
Table 1 Chemical composition, alloy type and heat trealment of the irradiated titanium alloys.

\begin{tabular}{|c|c|c|c|}
\hline Alloy composition & Alloy type & $\begin{array}{c}\text { Alloy } \\
\text { designation }\end{array}$ & Heat treatment \\
\hline Ti.6Al.4V & Alpha + Beta & Ti.6.4(MA) & $\begin{array}{l}\text { Mill anneal: } \\
730^{\circ} \mathrm{C} / 2 \mathrm{~h} \text {. Air cool to } 25^{\circ} \mathrm{C}\end{array}$ \\
\hline Ti.6Al.4V & Alpha + Beta & Ti.6.4(DUP) & $\begin{array}{l}\text { Duplex anneal; } \\
940^{\circ} \mathrm{C} / 10 \mathrm{~min} \text {, argon quench to } 25^{\circ} \mathrm{C} \\
+675^{\circ} \mathrm{C} / 4 \mathrm{~h} \text {, air cool to } 25^{\circ} \mathrm{C}\end{array}$ \\
\hline $\mathrm{Ti} .6 \mathrm{Al} .4 \mathrm{~V}$ & Alpha + Beta & $T i \cdot 6.4(B A)$ & $\begin{array}{l}\text { Beta anneal: } \\
1040^{\circ} \mathrm{C} / 30 \mathrm{~min} \text {, air cool to } 25^{\circ} \mathrm{C} \\
+730^{\circ} \mathrm{C} / 2 \mathrm{~h} \text {, air cool to } 25^{\circ} \mathrm{C}\end{array}$ \\
\hline Ti-6Al-2Sn-4Zr-2Mo-0.09Si & Near-Alpha & Ti.6242S(DUP) & $\begin{array}{l}\text { Duplex anneal; } \\
900^{\circ} \mathrm{C} / 30 \mathrm{~min} \text {, air cool to } 25^{\circ} \mathrm{C} \\
+790^{\circ} \mathrm{C} / 15 \mathrm{~min} \text {, air cool to } 25^{\circ} \mathrm{C} \\
\end{array}$ \\
\hline Ti.5Al-6Sn-2Zr-1Mo-0.2Si & Near-Alpha & Ti.5621S(DUP) & $\begin{array}{l}\text { Duplex anneal; } \\
950^{\circ} \mathrm{C} / 15 \mathrm{~min} \text {, air cool to } 25^{\circ} \mathrm{C} \\
+600^{\circ} \mathrm{C} / 2 \mathrm{~h} \text {, air cool to } 25^{\circ} \mathrm{C}\end{array}$ \\
\hline Ti.15V.3Cr.3Al.3Sn & Beta & $T i \cdot 15 \cdot 3 \cdot 3 \cdot 3(\mathrm{STA})$ & $\begin{array}{l}\text { Solution-treat-and-age; } \\
760^{\circ} \mathrm{C} / 15 \mathrm{~min} \text {, air cool to } 25^{\circ} \mathrm{C} \\
+510^{\circ} \mathrm{C} / 16 \mathrm{~h} \text {, air cool to } 25^{\circ} \mathrm{C}\end{array}$ \\
\hline
\end{tabular}



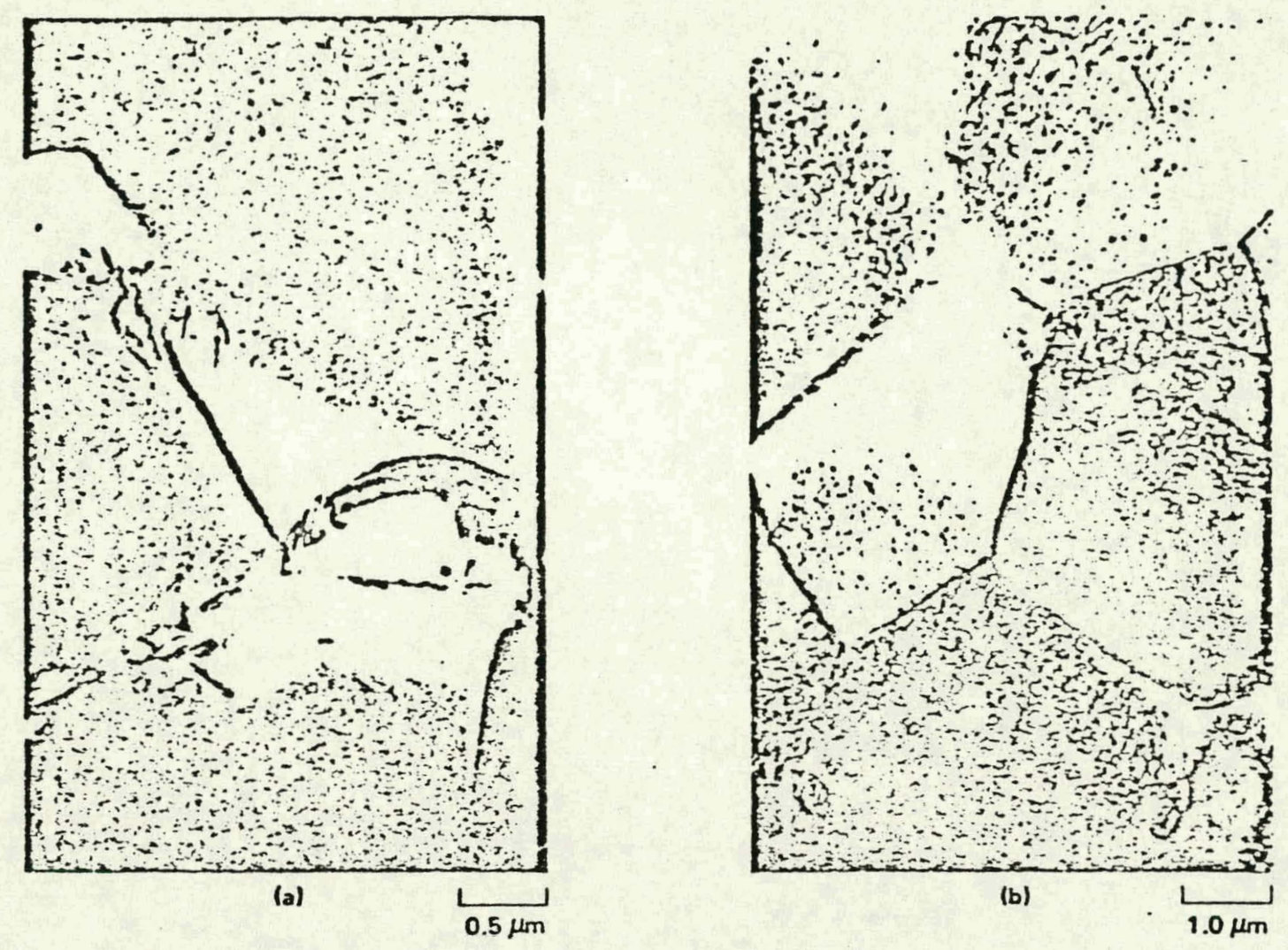

Finure 1.Microstructures of duplex-annealed Ti.6Al.4V; (a) unirradiated and (b) after neutron irradiation to a fluence $\approx 3 \times 10^{21} \mathrm{nicm} \mathrm{cm}^{2}$.
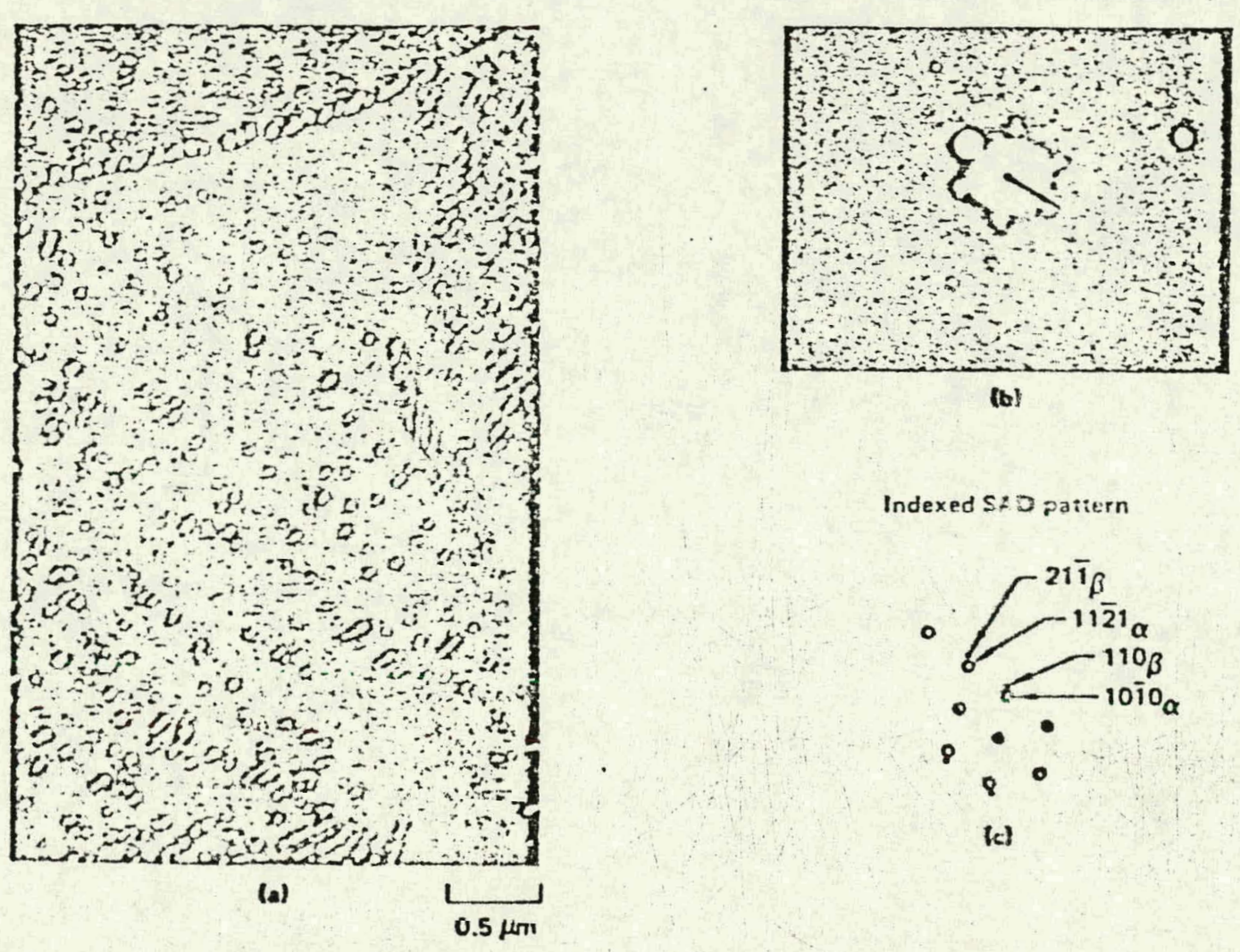

(b)

Indexed SZD patiern

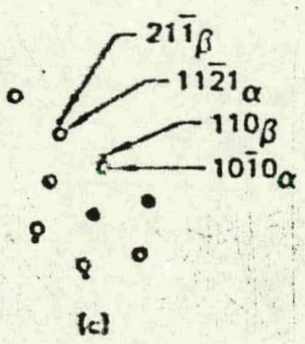

Figure 2. Morphology and orienlation of nonequilibrium precipitates in irradiated duplex-annealed Ti.GAI.4V; (a) dark-lield electron microgtaph of precipitates, 

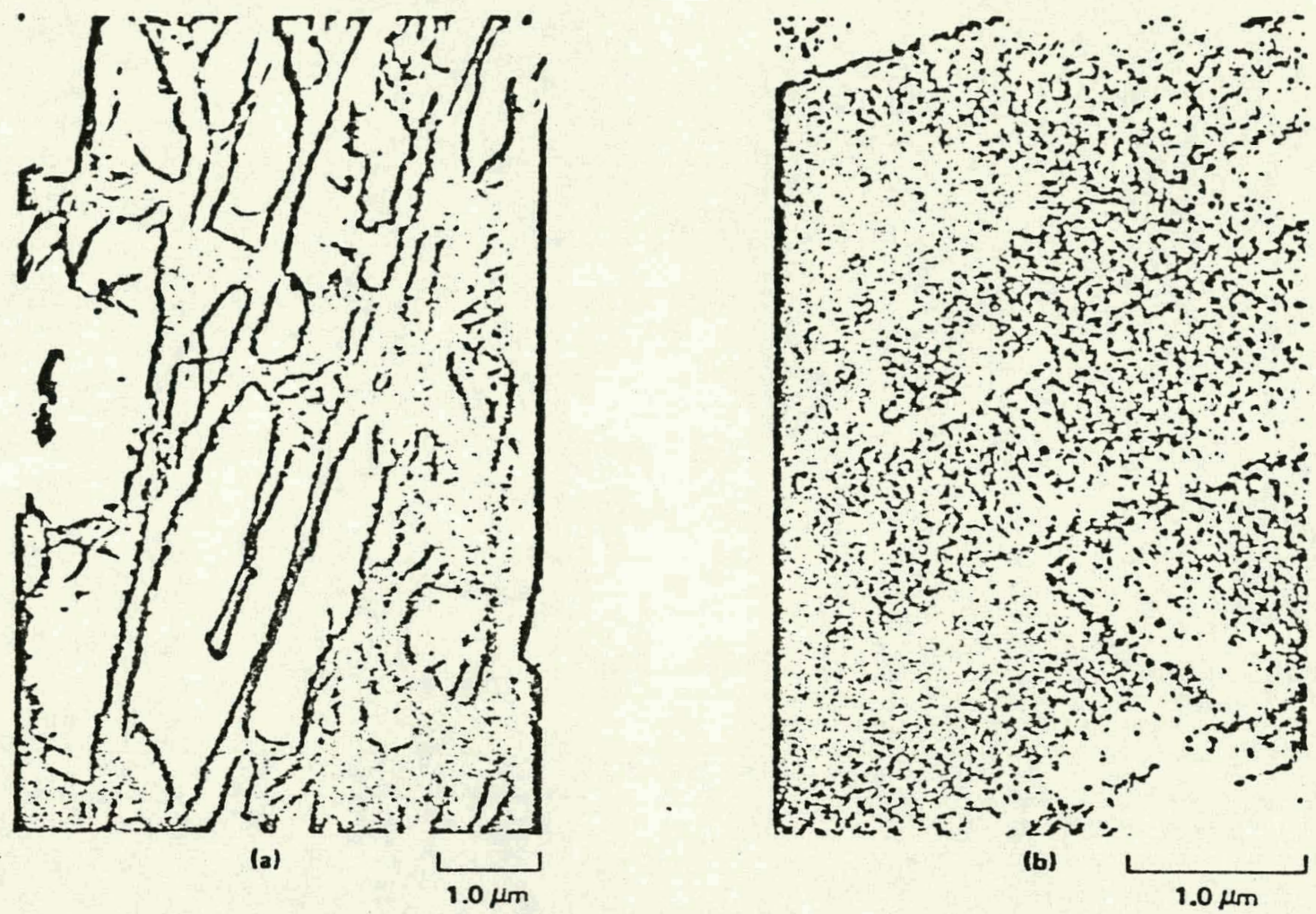

Figure 3. Microstructures of beta-annealed Ti.6Al-4V; (a) unirradiated, showing Widmanstätten $\alpha-\beta$ platlets and (b) irradiated, showing a high density of defects and precipitates in the $\alpha$ plates.
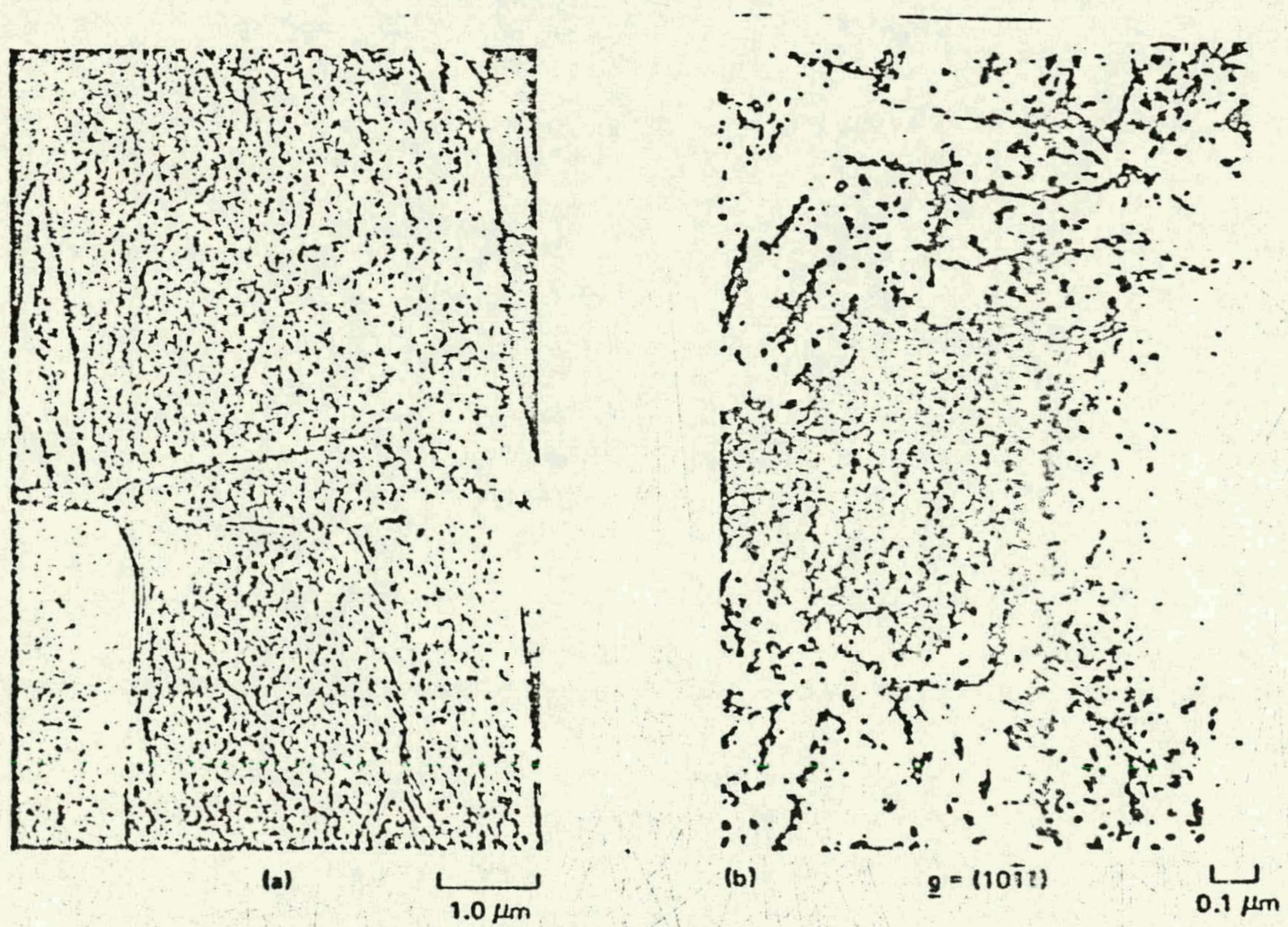

Figure 4. Defect microstructure in irradialed Ti.5Al.6Sn-2Zr-1Mo.0.3Si; (a) low. magnilication micrograph and (b) high-magnification micrograph showing the details of dislocation loops. 

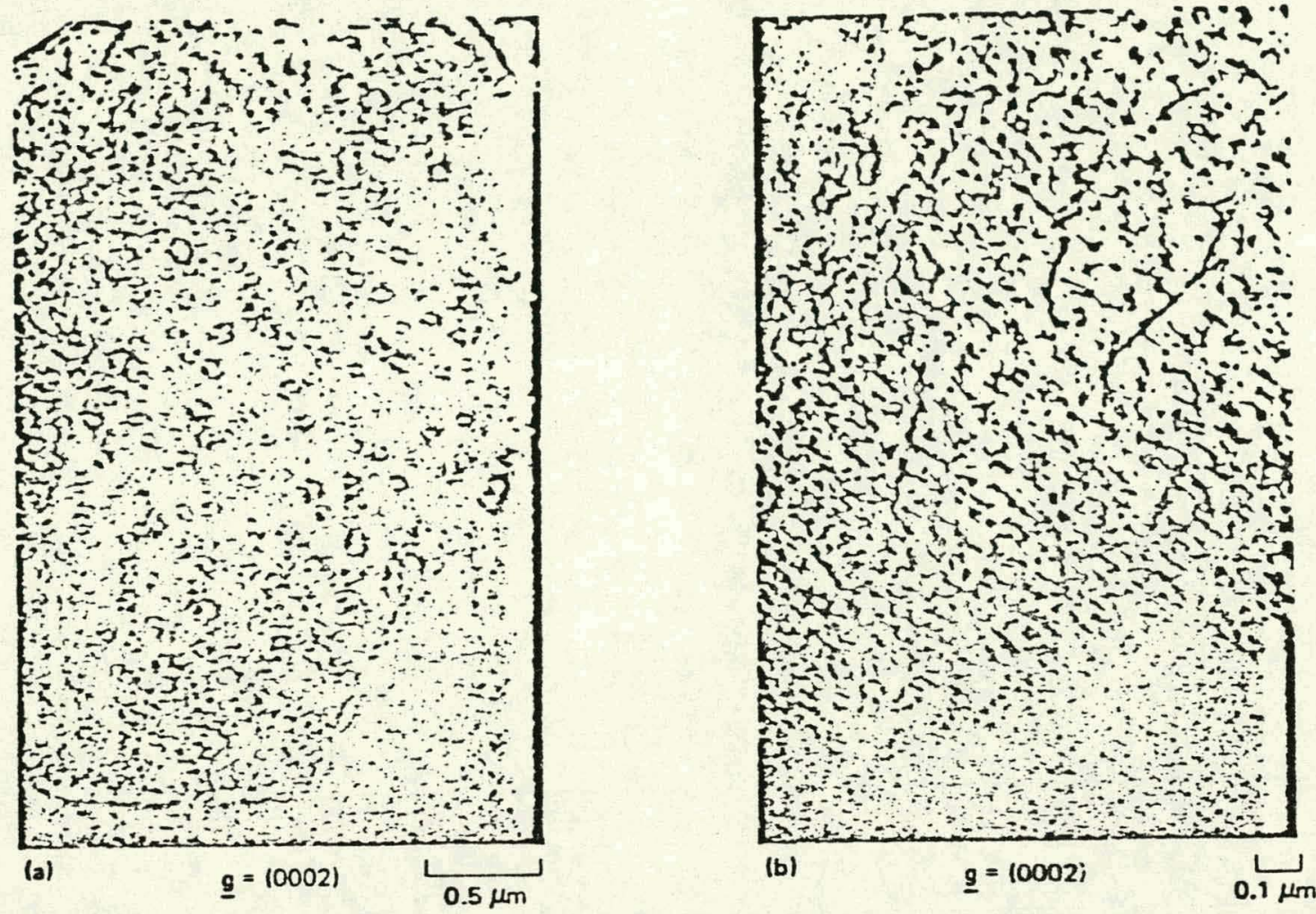

Figure 5. Defect structure in Ti-5 Al-6Sn-2Zr-1Mo-0.2Si imaged with $\mathrm{g}=(0002)$; (a) dislocation loops showing black-white contrast and (b) $\underline{c}$-component dislocations detained at defect clusters.
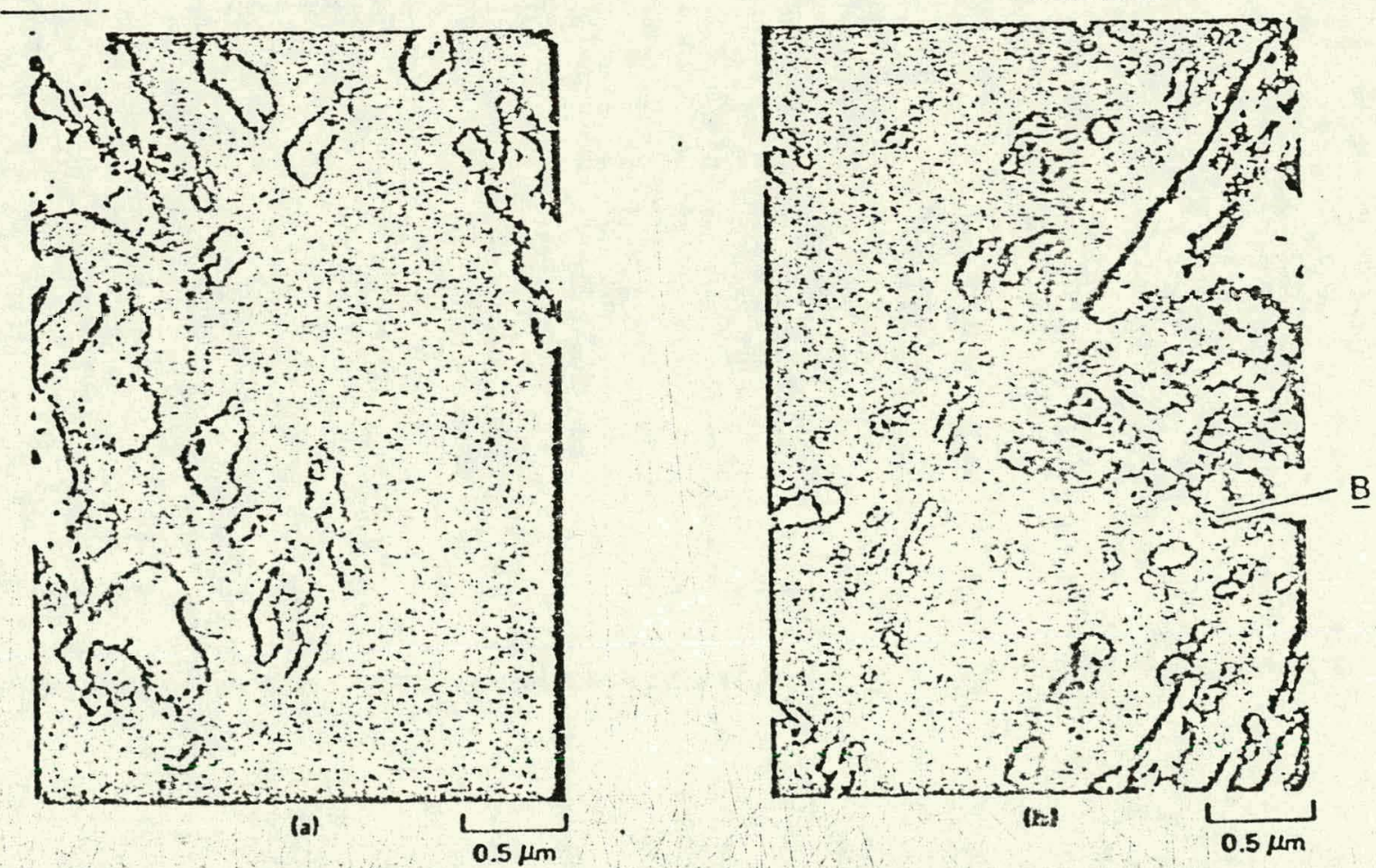

Figure 6.Microstructures of Ti.15V-3Cr-3Al.3Sn; (a) unirradiated, showing the equilibrium a precipitates in the solution-treat-and-aged condition and (b) irradialed, showing additional a precipitates and spheroidization of $\alpha$ at $\underline{B}$. 


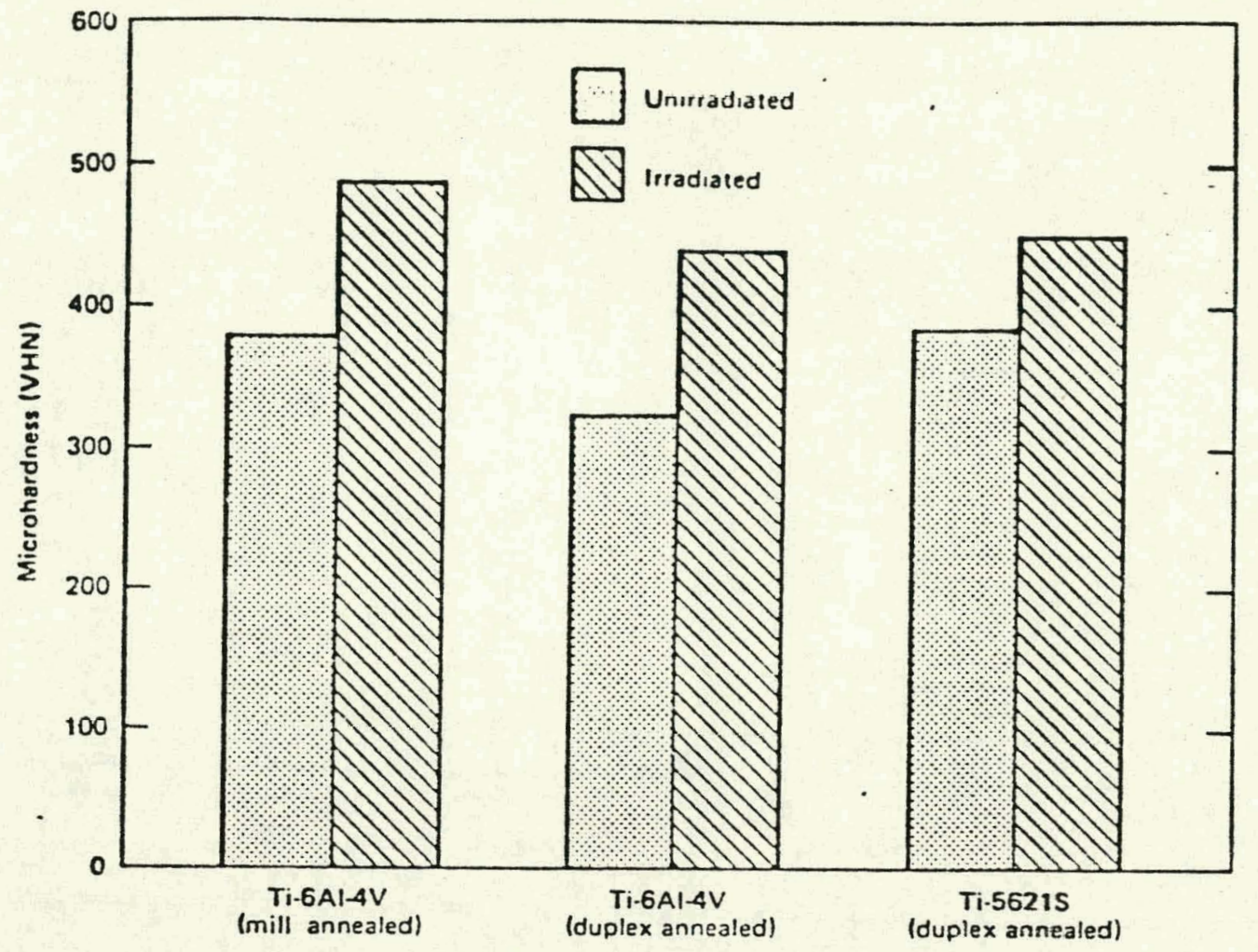

Figure 7. Effect of neutron irradiation on the hardness of titanium alloys.
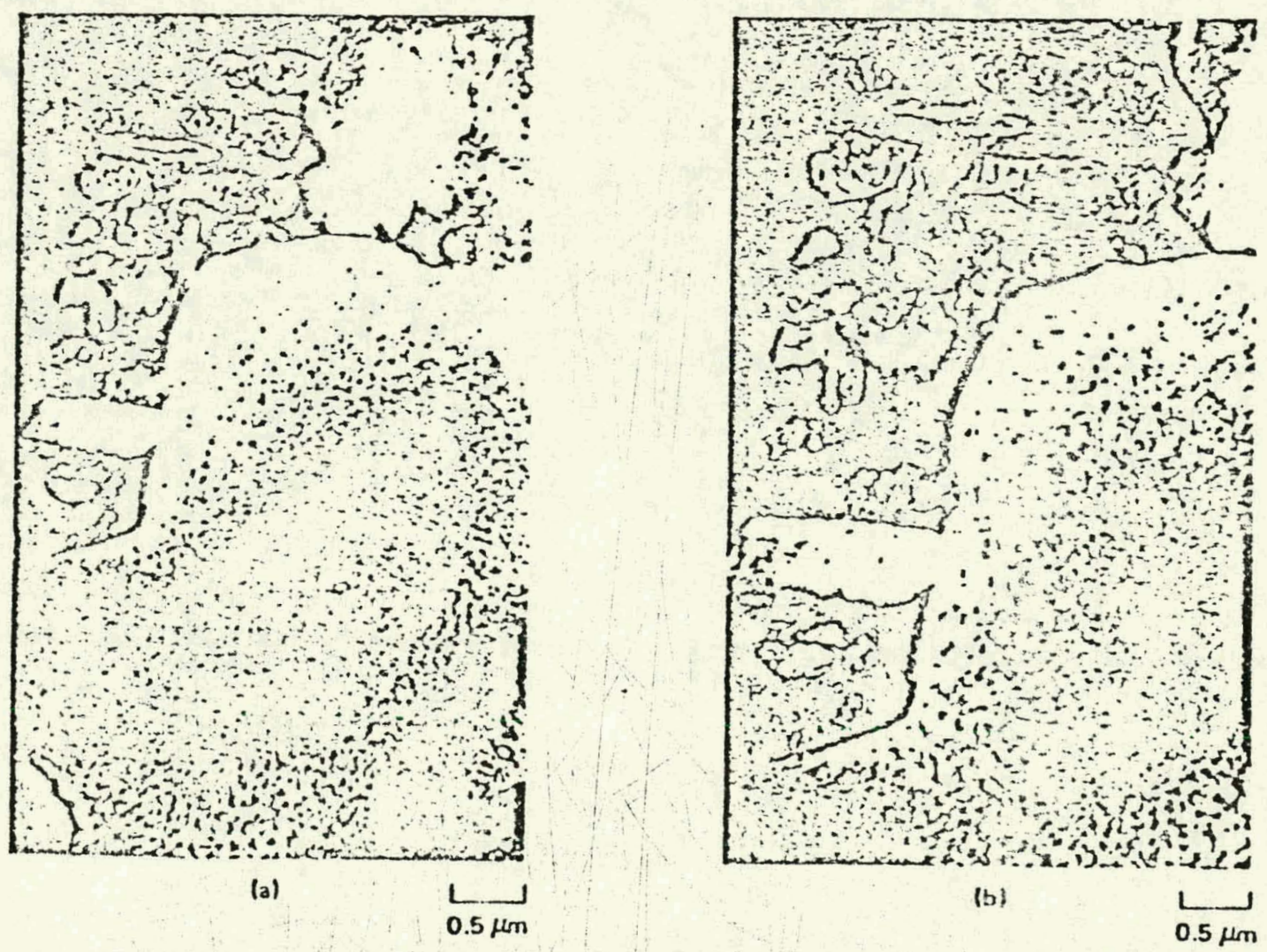

Figure 8. Microstructures of irradiated duplex-annealed Ti-6Al-4V after in situ annealing (a) at $500^{\circ} \mathrm{C}$ for $10 \mathrm{~min}$ and (b) at $560^{\circ} \mathrm{C}$ for $10 \mathrm{~min}$. 

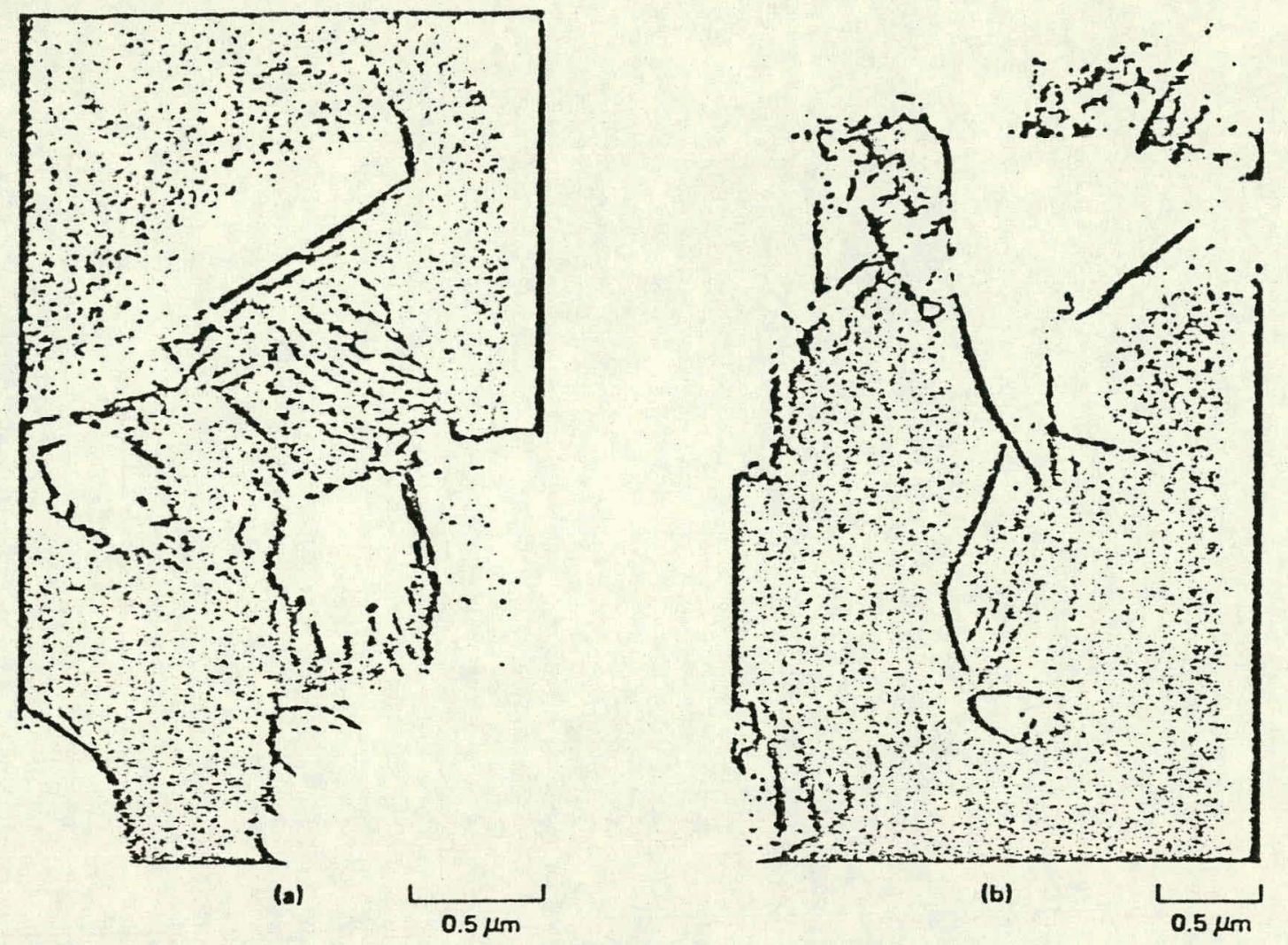

Figure 9. Microstructures of irradiated titanium alloys annealed at $650^{\circ} \mathrm{C}$ for $24 \mathrm{~h}$; (a) Ti-6Al-4V and (b) Ti.6Al-2Sn-4Zr-2Mo-0.09Si.

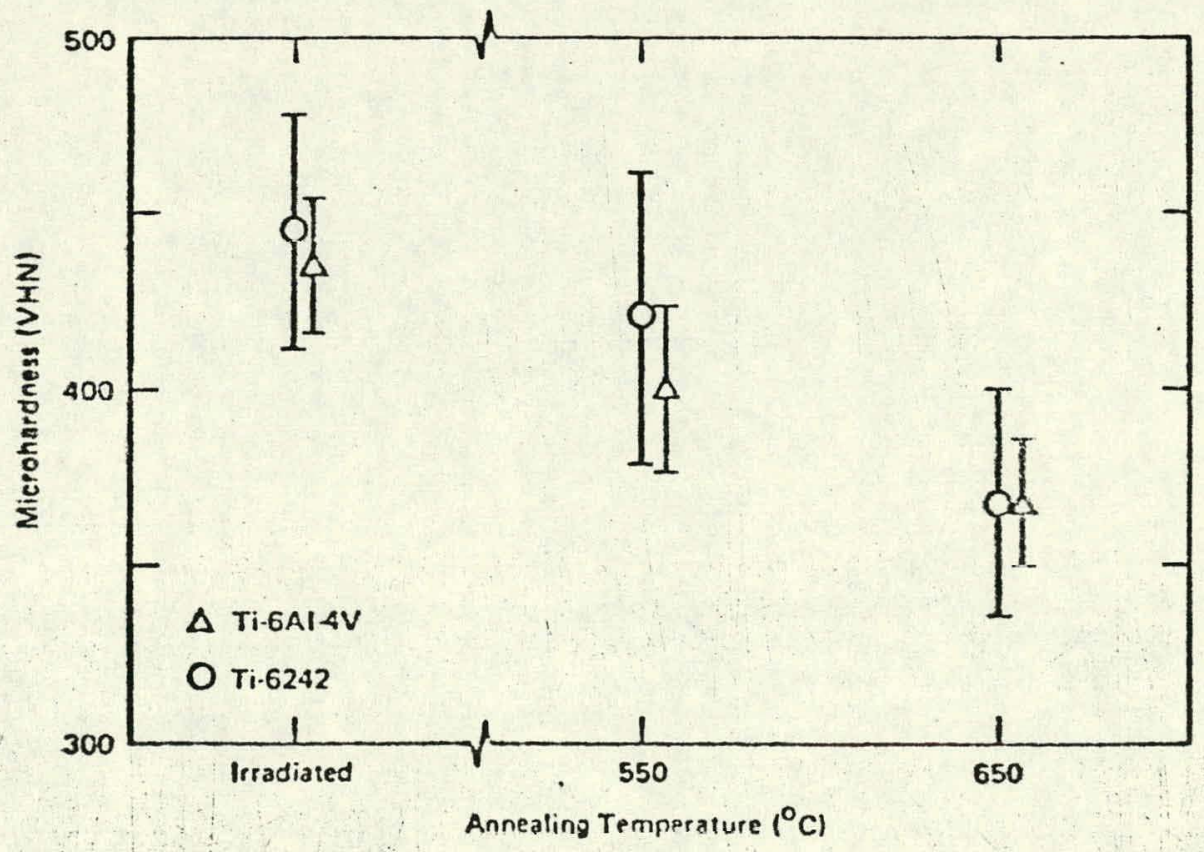

Figure 10. Influence of annealing on hardness of irradiated titanium alloys. 